\title{
Indeks Masa Tubuh (IMT): Kajian Analisis Pada Atlet Renang Junior Usia Sekolah Dasar
}

\author{
Didik Rilastiyo Budi $^{1 *}$, Arfin Deri Listiandi ${ }^{1}$, Rifqi Festiawan ${ }^{1}$, Neva Widanita ${ }^{1}$, Dewi Anggraeni ${ }^{1}$ \\ ${ }^{1}$ Universitas Jenderal Soedirman, Indonesia.
}

\section{Info Artikel}

Sejarah Artikel:

Diterima April 2020

Disetujui April 2020

Dipublikasikan Mei 2020

\section{Keywords:}

Atlet Junior, Indeks Masa Tubuh, Renang.

\begin{abstract}
Abstrak
Renang merupakan salah satu olahraga terukur yang dipengaruhi oleh beberapa faktor untuk dapat melakukan berbagai teknik gaya renang dengan baik, salah satu faktor yang penting dan belum dikaji secara lebih dalam yaitu mengenai Indeks Masa Tubuh (IMT) dari atlet renang junior. Tujuan penelitian ini yaitu ingin meganalisis karakteristik Indeks Masa Tubuh (IMT) pada atlet renang junior usia Sekolah Dasar. Metode penelitian yang digunakan yaitu penelitian ex-postfacto. Populasi pada penelitian ini adalah atlet renang junior di klub renang Tirta Kembar Purwokerto, sedangkan sampel penelitian yaitu seluruh atlet renang junior usia sekolah dasar dengan rata-rata umur 10 tahun yang berjumlah 20 anak dan terdiri dari 14 atlet putri dan 6 atlet putra, menggunakan teknik total sampling. Pengumpulan data dilakukan dengan mengunakan instrumen Indeks Masa Tubuh (IMT) dengan validitas dan reliabilitas 0,98. Analisis data menggunakan Penilaian Acuan Patokan (PAP) berdasarkan kriteria Indeks Masa Tubuh (IMT) dan kemudian dianalisis mengunakan bantuan Ms. Excel. Hasil penelitian menunjukan bahwa Indeks Masa Tubuh (IMT) atlet renang junior usia sekolah dasar di klub renang Tirta Kembar Purwokerto menunjukan nila rata-rata pada rentan IMT Kurus, akan tetapi terdapat dua atlet junior putri yang berada pada IMT dengan kriteria berat badan lebih, dengan jumlah prosentase IMT Kurus 65\%, IMT Normal 25\%, IMT Kelebihan Berat Badan 10\% dan tidak ada anak dalam kategori Obesitas. Kesimpulan dari penelitian ini yaitu, rata-rata atlet renang junior usia sekolah dasar memilki kategori IMT kurus, sehingga kurang ideal untuk seorang atlet renang di usia junior. Saran dari penelitian ini yaitu perlu adanya perhatian khusus dari orang tua dan pelatih mengenai asupan gizi pada anak, sehingga anak dapat memiliki kriteria IMT pada kategiori normal sesuai dengan usianya, serta terhindar dari resiko kekurangan gizi dan kegemukan/obesitas.
\end{abstract}

\begin{abstract}
Swimming is one of the measured sports that is influenced by several factors to be able to perform a variety of swimming style techniques well, one of the important factors and has not been studied more deeply, namely regarding the Body Mass Index (BMI) of junior swimming athletes. The purpose of this study is to analyze the characteristics of the Body Mass Index (BMI) in junior high school age junior athletes. The research method used is ex-postfacto research. The population of this study is junior swimming athletes at the Tirta Kembar Purwokerto swimming club, while the study sample is all junior swimming athletes of elementary school age with an average age of 10 years totaling 20 children and consisting of 14 female athletes and 6 male athletes, using techniques total sampling. Data collection was performed using the Body Mass Index (BMI) instrument with a validity and reliability of 0.98. Data analysis used the Benchmark Reference Assessment (PAP) based on the Body Mass Index (IMT) criteria and then analyzed using Ms. assistance. Excel. The results showed that the Body Mass Index (BMI) of junior high school age swimming athletes at the Tirta Kembar Purwokerto swimming club showed an average value of vulnerable BMI, but there were two junior female athletes who were at BMI with overweight criteria, with the percentage of BMI less than $65 \%, B M I$ Normal $25 \%, B M I$ Overweight $10 \%$ and no children in the category of Obesity. The conclusion of this study is that, on average junior swimming athletes of primary school age have a thin IMT category, so it is less ideal for a swimming athlete at junior age. Suggestion of this study is that there needs to be special attention from parents and trainers regarding nutritional intake in children, so that children can have BMI criteria in the normal category according to their age, and avoid the risk of malnutrition and obesity.
\end{abstract}




\section{PENDAHULUAN}

Indeks Masa Tubuh (IMT) pada perkembangannya menjadi bahan kajian yang penting, karena dengan mengetahui Indeks Masa Tubuh maka dapat diketahui apakah seseorang berada pada kategori kurus, normal, overwight atau obesitas. Status gizi, dalam hal ini obesitas pada anak sekolah dapat diprediksi dengan mengukur indeks masa tubuh (Nurhasan \& Narlan, 2011). Hasil Riset Kesehatan Dasar (Riskedas, 2013) di Indonesia pada anak sekolah usia 5-12 tahun menunjukkan sebanyak $11,2 \%$ berada pada kategori kurus, 30,7\% normal dan 18,8 \% kegemukan/Obesitas. Lebih lanjut hasil penelitian lain yang dilaukan pada anak Sekolah Dasar kelas IV di Kecamatan Baturaden, Kabupaten Banyumas menunjukkan bahwa 9,9 \% anak sekolah kurus dan 12,2\% mengalami kegemukan (Purnamasari et al., 2015). Berdasarkan hasil penelitian terdahulu dapat disimpulkan bahawa pada usia anak Sekolah Dasar yang berkisar antar usia 6-12 tahun terdapat resiko kegemukan dan obesitas pada anak.

Resiko kegemukan dan obesitas yang terjadi pada anak usia Sekolah Dasar berkaitan erat dengan pola makan dan aktivitas fisik yang dilakukan. Makanan cepat saji (Junk-/Fastfood) yang semakin marak menjadi faktor pemicu terhadap buruknya status gizi dan kesehatan (Kusuma et al., 2019). Pola aktivitas fisik masyarakat cenderung bergeser menjadi sedentary lifestyle yang disebabkan oleh kemajuan teknologi dan mengakibatkan peningkatan resiko obesitas (Popkin et al., 2012). Permainan game online membuat kurangnya aktivitas fisik secara menyeluruh terutama bagi anak-anak Wahono et al (2019). Perubahan pola makan dan aktivitas fisik pada anak menjadikan pertumbuhan fisik dan perkembangan motorik anak dapat terganggu.

Secara karakteristik, anak usia Sekolah Dasar memiliki ketertarikan dalam melakukan berbagai aktivitas fisik dalam bentuk permainan, sehingga secara alamiah, anak-anak memiliki ketertarikan dalam berbagai aktivitas olahraga. Aktivitas olahraga yang menyenangkan dapat membuat anak bersemangat dalam melaksanakan aktivitas fisik (Wahono et al., 2019). Masa anak-anak adalah saat dimana keterampilan motorik dan kognitif berkembang secara dinamis dan dapat dilakukan dengan aktivitas fisik yang menyenangkan (Budi et al., 2019). Berbagai aktivitas olahraga yang disenangi oleh anak diantaranya yaitu olahraga sepakbola, bulutangkis, renang dan sebagainya.

Aktivitas renang bagi anak-anak menjadi salah satu kegiatan olahraga yang menarik karena, anak dapat melakukan berbagai gerakan renang dalam bentuk yang bermacam-macam. Renang pada perkembangannya dapat meningkatkan keterampilan motorik dan mengembangkan potensi fisik dengan lebih optimal. Olahraga renang memiliki karakteristik selalu menggerakkan seluruh tubuh terutama tangan, kaki, badan dan kepala secara aktif (Setiaputri et al., 2017). Sehingga dengan selalu bergerak aktif selama melakukan gerakan renang maka akan dapat mendorong anak untuk meningkatkan ketrampilan motorik dan berdampak positif terhadap perkembangan fisik anak.

Perkembangan olahraga renang telah menyebar ke berbagai daerah, salah satunya yaitu Purwokerto. Purwokerto sebagai salah satu kota di Kabupaten Banyumas, memiliki masyarakat dengan animo yang cukup besar terhadap olahraga renang, hal ini ditunjukan dengan setiap sekolah dari Sekolah Dasar hingga Sekolah Menengah Atas memiliki program aktivitas renang dalam pembelajaran, selain itu juga terdapat beberapa sekolah yang mewajibkan siswanya mengikuti ektrakurikuler renang. Selain kegiatan di sekolah, renang juga menjadi aktivitas yang digemari oleh anak, hal ini ditunjukan dengan terdapat beberapa klub renang yang berada di daerah tersebut, diantaranya Klub Bina Taruna, Klub Renang Tirta Kencana, Klub Renang Tirta Kembar dan sebagainya. Klub renang di Purwokerto didominasi oleh para atlet renang pemula yang diantaranya yaitu anak usia Sekolah Dasar.

Salah satu klub renang yang membina atlet dari usia Sekolah Dasar yaitu Klub Renang Tirta Kembar, yang memiliki banyak atlet junior pada usia sekolah dasar. Pembinaan atlet usia dini merupakan salah satu faktor penting dalam pencapaian prestasi olahraga. Proses pemanduan bakat olahraga perlu dilakukan dari 
usia sedini mungkin, sehingga bakat-bakat calon atlet dapat ditemukan dengan tepat (Syafei et al., 2020). Dengan proses pembinaan yang menitik beratkan kepada atlet dengan rentan umur sekolah dasar, proses pembinaan atlet renang di Purwokerto telah berjalan dengan cukup baik. Namun yang perlu diperhatikan yaitu tidak hanya pemanduan dan pembinaan atlet usia sekolah dasar, akan teapi juga harus diperhatikan komposisi fisik anak yang dilihat dari segi tinggi dan berat badan.

Tinggi dan berat badan yang dimiliki akan berpengaruh terhadap indeks masa tubuh yang dimiliki. Dengan indeks masa tubuh yang ideal, anak dapat melakukan gerakan renang dengan lebih baik. Hasil penelitian terdahulu menunjukan bahwa keterampilan motorik umum lebih rendah pada anak-anak yang mengalami obesitas daripada rekan-rekan dengan berat badan normal dan kelebihan berat badan (D'Hondt et al., 2009). Kajian mengenai komposisi indeks masa tubuh yang dimiliki oleh atlet junior di klub renang Tirta Kembar Purwokerto belum pernah dilakukan, sehingga belum diketahui apakah anak-anak yang dibina memiliki komposisi tubuh yang ideal sebagai atlet renang junior atau tidak.

Pengukuran indeks masa tubuh pada pemilihan atlet junior belum dilaksanakn dengan baik karena, pada perekrutan anak yang mengikuti program latihan renang tidak dilaksanakan tes tinggi dan berat badan, sehingga komposisi tubuh yang dimiliki oleh anak tidak terpantau secara terukur. Hal ini jelas kurang menguntungkan apabila tujuan dari pembinaan tidak hanya untuk bergerak aktif dan menyenangi olahraga akan tetapi juga bertujuan untuk mencapai prestasi di cabang olahraga renang melalui berbagai kejuaraan di tingkat junior.

Hasil penelitian menunjukan bahwa pada perenang pemula, kekuatan lengan untuk mendorong pada saat berenang secara positif dipengaruhi oleh komposisi tubuh (IMT) dan karakteristik antopometri (Moura et al., 2014). Lebih lanjut, terdapat perbedaan yang signifikan antara karakteristik antropometrik seperti tinggi badan, berat badan, panjang lengan dan BMI terhadap kecepatan berenang (Barghamadi et al., 2012). Berdasarkan hasil peenlitian terdahulu maka komposisi tubuh pada atlet renang junior harus diperhatikan, apabila pada usia sekoilah dasar tidak memiliki komposisi tubuh yang ideal untuk ukuran seorang atlet renang maka, pada perkembangannya akan dapat mengganggu proses belajar keterampilan berbagai gaya dalam renang tersebut, yang pada jangka panjang dapat mengganggu pencapaian prestasi di masa depan. Tujuan dari penelitian ini yaitu ingin mengkaji mengenai Indeks Masa Tubuh yang dimiliki oleh atlet renang junior usia Sekolah Dasar di klub renang Tirta Kembar Purwokerto.

\section{METODE \\ Jenis penelitian}

Penelitian ini menggunakan metode deskriptif ex-postfacto. Metode ex-postfacto merupakan jenis penelitian yang tidak mempunyai kontrol langsung terhadap variabel (Sugiyono, 2016).

\section{Populasi}

Populasi pada penelitian ini adalah atlet renang junior sekolah dasar di Klub Renang Tirta Kembar Purwokerto, Kabupaten Banyumas. Sampel pada penelitian ini yaitu seluruh atlet renang junior yang berumur 10 tahun dan terdiri dari 14 orang putri dan 6 orang putra dengan total 20 atlet junior, dengan menggunakan teknik total sampling

\section{Teknik Pengumpulan Data}

Instrumen penelitian menggunakan tes Indeks Masa tubuh (IMT) dengan rumus penghitungan IMT yang dilakukan dengan mengambil data berat badan $(\mathrm{kg})$ dibagi tinggi badan $\left(\mathrm{m}^{2}\right)$ (Nurhasan \& Narlan, 2011).

Teknik pengumpulan data yang dilakukan yaitu dengan cara tes pengukuran tinggi dan berat badan pada sampel. Prosedur tes pengukuran berat dan tinggi badan mengadopsi dari (Nurhasan \& Narlan, 2011) dengan tingkat valisditas dan reliabilitas sebesar 0,98 , adapun prosedur pelaksanaan pengukuran indeks masa tubuh pada anak usia sekolah adalah sebagai berikut:

1. Alat yang digunakan yaitu pengukur tinggi dan berat badan yang standar.

2. Mengukur tinggi badan, dilakukan dengan 
cara peserta tes berdiri tegak, dengan posisi kepala menghadap ke depan, bahu tegak dan tidak ditarik ke belakang. Posisi kepala, bahu, siku, pinggul dan tumit menempel pada dinding.

3. Pengukuran berat badan, dilakukan dengan cara peserta berdiri tegak di atas timbangan dan tanpa menggunakan alas kaki. Berat badan diukur dengan alat timbang yang standar.

4. Penilaian dilakukan dengan cara skor tinggi badan dicatat dalam satuan meter $(\mathrm{m})$ dan skor berat badan dicatat dalam satuan kilogram (kg).

\section{Analisa data}

Analisi data menggunakan Penilaian Acuan Patokan (PAP) untuk mengukur kriteria Indeks Masa Tubuh (IMT) anak usia 5-18 berdasarkan data dari (Kemenkes, 2013) yang dapat di lihat pada tabel 1. di bawah ini :

Tabel 1. Klasifikasi IMT

\begin{tabular}{ll}
\hline Klasifikasi & $\begin{array}{l}\text { Indeks Masa Tubuh } \\
\text { (IMT) }\left(\mathbf{k g} / \mathbf{m}^{2}\right)\end{array}$ \\
\hline Kurus & IMT $<18,5$ \\
\hline Normal & IMT 18,5 - 25,89 \\
\hline Berat Badan Lebih & IMT 25,90 - 26,99 \\
\hline Obesitas & IMT 27 Ke atas \\
\hline
\end{tabular}

Data hasil pengukuran Indeks Masa Tubuh kemudian akan dianalisis dengan menggunakan bantuan aplikasi ms. Excel sehingga dari data tersebut dapat diketahui jumlah anak yang termasuk dalam kategori IMT Kurus, Normal, Berat Badan Lebih maupun Obesitas.

\section{HASIL DAN PEMBAHASAN}

Data hasil penelitian mengenai Indeks Masa Tubuh (IMT) atlet renang junior putri usia sekolah dasar pada klub renang Tirta Kembar Purwokerto menggunakan Penilaian Acuan Patokan (PAP), dapat dilihat pada tabel 2 dan gambar 2 berikut ini.

Berdasarkan tabel 2 dapat diketahui bahwa Indeks Masa Tubuh (IMT) yang dimiliki oleh atlet junior renang berjenis kelamin putri menunjukan 9 anak berada pada kategori Kurus, 3 anak kategori normal, 2 anak kategori berat badan lebih dan tidak ada anak yang memiliki IMT kategori obesitas.

Tabel 2. Indeks Masa Tubuh Atlet Renang Junior Putri

\begin{tabular}{ll}
\hline Klasifikasi & Jumlah (IMT) \\
\hline Kurus & 9 \\
\hline Normal & 3 \\
\hline Berat Badan Lebih & 2 \\
\hline Obesitas & 0 \\
\hline
\end{tabular}

Dari gambar 1 diketahui bahwa Indeks Masa Tubuh (IMT) atlet renang junior putri menunjukan $64,29 \%$ berada pada kategori Kurus, $21,43 \%$ berada pada kategori normal, $14,29 \%$ berada pada kategori berat badan lebih dan tidak ada anak yang memiliki IMT kategori obesitas. Hal ini menunjukan bahwa rata-rata Indek Masa Tubuh (IMT) pada atlet renang junior putri usia sekolah dasar memiliki ratarata IMT dengan kategori kurus.

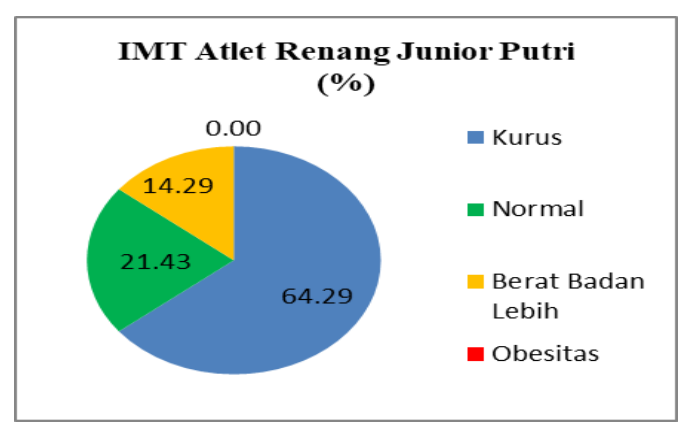

Gambar 1. Diagram Kriteria IMT Atlet Renang Junior Putri

Berikutnya data Indeks Masa Tubuh (IMT) pada atlet renang junior putra usia sekolah dasar pada klub renang Tirta Kembar Purwokerto berdasarkan Penilaian Acuan Patokan (PAP), dapat di lihat pada tabel 3 dan gambar 3 di bawah ini.

Tabel 3. Indeks Masa Tubuh Atlet Renang Junior Putra

\begin{tabular}{ll}
\hline Klasifikasi & Jumlah (IMT) \\
\hline Kurus & 4 \\
\hline Normal & 2 \\
\hline Berat Badan Lebih & 0 \\
\hline Obesitas & 0 \\
\hline
\end{tabular}


Pada tabel 3 dapat ketahui bahwa Indeks Masa Tubuh (IMT) yang dimiliki oleh atlet renang junior putra menunjukan 4 anak berada pada kategori Kurus, 2 anak kategori normal, serta tidak ada anak yang memiliki IMT kategori berat badan lebih dan obesitas.

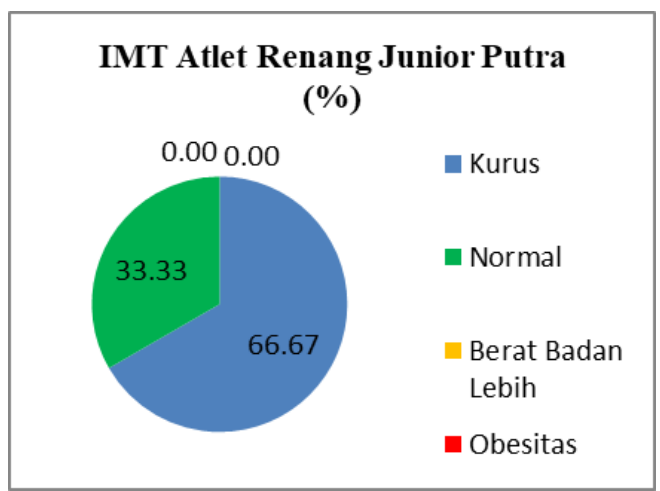

Gambar 3. Diagram Kriteria IMT Atlet Renang Junior Putra

Dari gambar 3 dapat ketahui bahwa Indeks Masa Tubuh (IMT) yang dimiliki oleh atlet renang junior putra menunjukan $66,67 \%$ berada pada kategori Kurus, 33,33\% berada pada kategori normal, serta tidak ada anak yang memiliki IMT kategori berat badan lebih dan obesitas. Hal ini menunjuka bahwa rata-rata Indek Masa Tubuh (IMT) pada atlet renang junior putra usia sekolah dasar memiliki ratarata IMT dengan kategori kurus.

Selanjutnya data Indeks Masa Tubuh (IMT) pada atlet renang junior putri dan putra usia sekolah dasar pada klub renang Tirta Kembar Purwokerto, dapat di lihat pada tabel 4 dan gambar 4.

Tabel 4. Indeks Masa Tubuh Atlet Renang Junior Putri dan Putra

\begin{tabular}{ll}
\hline Klasifikasi & Jumlah (IMT) \\
\hline Kurus & 13 \\
\hline Normal & 5 \\
\hline Berat Badan Lebih & 2 \\
\hline Obesitas & 0 \\
\hline
\end{tabular}

Data hasil pada tabel 4 dapat ketahui bahwa Indeks Masa Tubuh (IMT) yang dimiliki oleh atlet junior renang secara keseluruhan menunjukan 13 anak berada pada kategori kurus, 5 anak kategori normal, 2 anak kategori kelebihan berat badan, serta tidak ada anak yang memiliki IMT kategori obesitas.

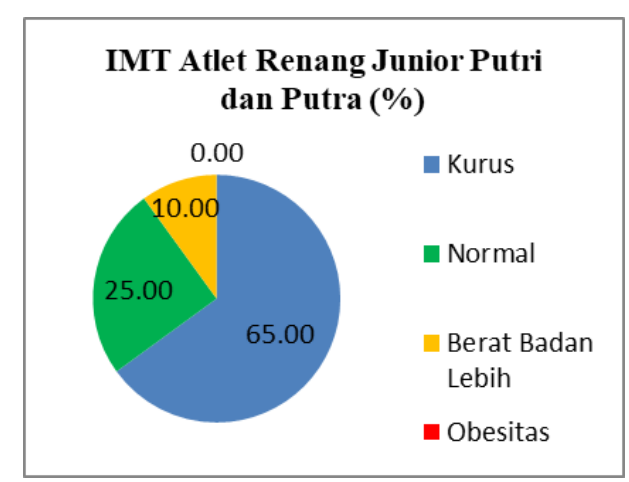

Gambar 4. Diagram Kriteria IMT Keseluruhan Atlet Renang Junior Usia Sekolah Dasar

Berdasarkan data pada tabel gambar 4 di atas dapat ketahui bahwa Indeks Masa Tubuh (IMT) yang dimiliki oleh atlet junior renang secara keseluruhan menunjukan $65 \%$ berada pada kategori kurus, $25 \%$ berada pada kategori normal, $10 \%$ berada pada kategori kelebihan berat badan, dan tidak ada anak yang memiliki IMT kategori obesitas. Hal ini menunjukan bahwa Indek Masa Tubuh (IMT) pada atlet renang junior usia sekolah dasar memiliki ratarata IMT dengan kategori kurus.

Hasil peneltiian diketahui bahwa pada kelompok atlet renang junior usia sekolah dasar memiliki rata-rata Indeks Masa Tubuh (IMT) dengan kriteria kurus. Hal ini menunjukan bahawa atllet renang junior di klub renang Tirta Kembar Purwokerto harus meningkatkan porsi makan dengan gizi yang baik sehingga dapat meningkatkan Indeks Masa Tubuh (IMT) ke level Normal, karena dengan pola latihan yang sudah terprogram apabila tidak diimbangi dengan pola makan yang baik maka pertumbuhan anak dalam hal ini Indeks Masa Tubuh (IMT) dapat terganggu perkembangannya. Hasil penelitian terdahulu menunjukan Aktivitas fisik siswa SD yang lebih tinggi dibandingkan total asupan energi mempengaruhi indeks massa tubuh (IMT) yang dimiliki siswa (Ariani \& AF, 2017). Lebih lanjut untuk dapat mencapai performa olahraga yang maksimal, atlet juga harus memperhatikan pola latihan yang disiplin dan juga mencukupi kebutuhan energinya menurut Williams (dalam 
Faruq \& Adiningsih, 2017). Sehingga untuk dapat memperoleh Indeks Masa Tubuh yang normal atau ideal, orang tua dan pelatih harus meperhatikan pola makan pada atlet junior.

Selain itu, data juga menunjukan terdapat dua atlet putri yang berada pada kondisi Indeks Masa Tubuh (IMT) di level kelebihan berat badan. Kecenderungan kelebihan berat badan secara umum sering terjadi kepada anak-anak putri sekolah dasar, hasil penelitian terdahulu menunjukan bahwa terdapat $10,3 \%$ siswa putri sekolah dasar yang mengalami kelebihan berat badan atau obesitas (Prihatmoko \& Nurhayati, 2019). Terjadinnya kelebihan berat badan pada atlet renang putri junior menunjukan bahwa program latihan yang dilakukan belum dapat secara signifikan untuk membantu anak berada pada level IMT normal atau ideal sesuai dengan umur anak. Selain program latihan, tentu faktor makanan dan istirahat yang dilakukan juga dapat mempengaruhi terjadinya kelebihan berat badan pada atlet. Faktor sosio-economic status menjadi faktor yang berkontribusi terhadap pemenuhan keterampilan motorik dan BMI, namun kondisi demografi lebih dominan berperan (Putri, et al, 2020). Kelebihan lemak tubuh akan meningkatkan massa tubuh sehingga menurunkan kecepatan, berat badan dengan komposisi lemak yang berlebih dapat menyebabkan kelelahan yang lebih cepat pada saat melakukan aktivitas berenang (Setiaputri et al., 2017). Oleh sebab itu atlet junior putri perlu memiliki berat bada idela untuk dapat melakukan latihan gerakan renang dengan lebih maksimal.

Kondisi Indeks Masa Tubuh (IMT) pada atlet renang junior putra pada klub renang Tirta Kembar Purwokerto memiliki karakter yang hampir sama dengan atlet junior putri, yaitu memiliki rata-rata Indek Masa Tubuh (IMT) dengan kategori kurus, dan hanya dua anak yang memiliki IMT Normal atau ideal. Perbedaan yang terdapat antar atlet junior putri dan putra yaitu, pada atlet junior putra tidak terdapat anak dengan kondisi IMT kelebihan berat badan. Hasil ini menunjukan bahwa atlet junior putra memiliki mobilitas gerak yang lebih tinggi daripada atlet putri, dan memiliki pola asupan gizi sedikit lebih baik. Hasil penelitian terdahulu menunjukan kelebihan berat badan dan BMI memiliki hubungan yang signifikan terhadap keterampilan renang pada atlet putri, dan tidak terlalu berpengaruh pada atlet putra (Dassanayake, 2016).

Secara keseluruhan atlet renang junior usia sekolah dasar, baik putri maupun putra memiliki rata-rata Indeks Masa Tubuhn (IMT) pada kategori kurus. Berdasarkan hasil tersebut maka perlu adanya perhatian khusus oleh pelatih dan orang tua untuk dapat meningkatkan Indeks Masa Tubuh (IMT) anak ke dalam kondisi normal, sehinga dapat menunjang gerakan renang dengan lebih optimal. Hasil penelitian terdahulu menunjukan bahwa pada anak laki-laki berusia 7-18 tahun dan anak perempuan usia 10-14 tahun, dengan BMI normal memiliki aktivitas fisik yang lebih tinggi dari pada kelompok BMI rendah maupun berat badan lebih/obesitas (Bi et al., 2019). Kemudian lemak tubuh dalam komposisi normal dan tinggi badan berkorelasi positif dan signifikan dengan kekuatan pendorong lengan pada saat berenang (Moura et al., 2014).

Lebih lanjut hasil penelitian juga memperkuat bahwa komposisi Indeks Masa Tubuh (IMT) normal memberikan pengaruh yang signifikan dalam aktivitas berenang. Landaeta-Jiménez et al (dalam Moura et al., 2014) menganalisis pertumbuhan fisik dan komposisi tubuh dari 178 perenang (114 pria dan 64 wanita) berusia antara 7 dan 18 tahun menunjukan bahwa perenang memiliki ukuran tubuh yang lebih besar tetapi memiliki kandungan lemak yang lebih sedikit. Berdasarkan hasil penelitian tersebut maka komposisi tubuh dengan BMI normal sangat diperlukan oleh atlet junior renang baik lakilaki maupun permepuan. Hasil penelitian (Faruq \& Adiningsih, 2017) menunjukan atlet renang dalam status gizi normal sesuai dengan indikator Indeks Massa Tubuh sangat mendukung kecepatan pergerakan pada saat berenang.

Dengan IMT normal sesuai dengan usia pertumbuhan dan perkembangan, maka anak diharapkan tidak terhambat proses pertumbuhan dan perkembangan, khusunya pada aspek antopometri, karena untuk atlet renang, komposisi antopometri memilki kontribusi yang penting untuk memperoleh kecepatan berenang. Hasil penelitian terdahulu menunjukan bahwa aspek antropometrik menyumbang 45,8\% 
pengaruh dalam kecepatan renang pada jarak 100 meter (Lätt et al., 2010).

\section{KESIMPULAN}

Berdasarkan hasil dan pembahasan penelitian diketahui bahwa rata-rata atlet renang junior usia sekolah dasar yang berlatih di klub Tirta Kembar memiliki rata-rata Indeks Masa Tubuh (IMT) pada kategori kurus, selain itu pada hasil penelitian juga teridentifikasi bahwa terdapat dua orang atlet putri yang memiliki Indeks Masa Tubuh (IMT) pada kategori kelebihan berat badan. Sehingga perlu adanya perhatian khusus kepada para atlet junior tersebut untuk dapat meningkatkan Indeks Masa Tubuh (IMT) yang dimiliki ke level IMT Normal, karena dengan memiliki IMT yang normal sesuai dengan umur anak, maka diharapkan dapat menunjang dalam peningkatan keterampilan gaya renang yang dapat meningkatkan prestasi pada usia selanjutnya.

Saran bagi penelitian selanjutnya dapat mengkaji mengenai Indeks Masa Tubuh (IMT) paada anak sekolah dasar yang ditinjau dari pola makan, pola tidur dan aktivitas fisik yang dilakukan, selain itu juga dapat mengidentifikasi mengenai program latihan yang dilakukan oleh atlet junior usia sekolah dasar dan dikaitkan dengan IMT pada anak.

\section{DAFTAR PUSTAKA}

Ariani, N. L., \& AF, S. M. (2017). Keterkaitan Aktivitas Fisik Dengan Indeks Massa Tubuh (IMT) Siswa SD Kota Malang. Care: Jurnal Ilmiah Ilmu Kesehatan, 5 (3), $457 . \quad$ https://doi.org/10.33366/ cr.v5i3.712

Barghamadi, M., Behboodi, Z., \& Toor, S. D. (2012). Biomechanical Factors in $200 \mathrm{~m}$ Freestyle Swimming and Their Relationships with Anthropometric Characteristics. Iranian Journal of Health and Physical Activity. Iranian Journal of Health and Physical Activity, 3(2), 49-54. https:// doi.org/https://doi.org/10.22067/

ijhpa.v3i2.16314

Bi, C., Yang, J., Sun, J., Song, Y., Wu, X., \& Zhang, F. (2019). Benefits of normal body mass index on physical fitness: A crosssectional study among children and adolescents in Xinjiang Uyghur Autonomous Region, China. PLOS ONE, 14(8). https:// doi.org/10.1371/journal.pone.0220863

Budi, D. R., Kusuma, M. N. H., Syafei, M., \& Stephani, M. R. (2019). The Analysis of Fundamental Movement Skill in Primary School Student in Mountain Range. 195$198 . \quad$ https://doi.org/10.2991/icsshpe18.2019 .56

D'Hondt, E., Deforche, B., De Bourdeaudhuij, I., \& Lenoir, M. (2009). Relationship between motor skill and body mass index in 5- to 10-year-old children. Adapted Physical Activity Quarterly, 26(1), 21-37. https://doi.org/10.1123/apaq.26.1.21

Dassanayake, S. (2016). Comparison of BMI and Body Fat Percentages between National Level Teenage Swimmers and Controls. Advances in Obesity, Weight Management \& Control, 4(6). https:// doi.org/10.15406/aowmc.2016.04.00109

Faruq, M. M. Al, \& Adiningsih, S. (2017). Pola Konsumsi Energi, Protein, Persen Lemak Tubuh dan Aerobic Endurance Atlet Renang Remaja. Media Gizi Indonesia, 10 (2), 117-122. https://doi.org/10.20473/ MGI.V10I2.117-122

Kemenkes. (2013). Pedoman gizi olahraga prestasi. Bina Gizi dan KIA.

Kusuma, M. N. H., Syafei, M., \& Rilastiyo, D. (2019). The Effect of Nutritional Status, Level of Physical Activity and Hemoglobins on Physical Endurance. JUARA: Jurnal Olahraga, 4(2), 186-195. https:// doi.org/10.33222/juara.v4i2.607

Lätt, E., Jürimäe, J., Mäestu, J., Purge, P., Rämson, R., Haljaste, K., Keskinen, K. L., Rodriguez, F. A., \& Jürimäe, T. (2010). Physiological, biomechanical and anthropometrical predictors of sprint swimming performance in adolescent swimmers. Journal of Sports Science and Medicine, 9 (3), 398-404.

Moura, T., Costa, M., Oliveira, S., Júnior, M. B., Ritti-Dias, R., \& Santos, M. (2014). Height and Body Composition Determine Arm Propulsive Force in Youth Swimmers Independent of a Maturation Stage. Journal of Human Kinetics, 42(1), 277284. https://doi.org/10.2478/hukin-20140081

Nurhasan, \& Narlan, A. (2011). Tes dan Pengukuran Pendidikan Olahraga. Pendidikan Jasmani Kesehatan dan Rekreasi, Universitas Siliwangi.

Popkin, B. M., Adair, L. S., \& Ng, S. W. (2012). Global nutrition transition and the 
pandemic of obesity in developing countries. Nutrition Reviews, 70(1), 3-21. https://doi.org/10.1111/j.1753-

4887.2011.00456.x

Prihatmoko, A. D., \& Nurhayati, F. (2019). Survei Status Gizi Berdasarkan TB/U Dan IMT/U Pada Siswa Kelas I (Satu) SD SeKecamatan Pacitan. Jurnal Pendidikan Olahraga Dan Kesehatan, 7(2), 287-291.

Purnamasari, D. U., Dardjito, E., \& Kusnandar, K. (2015). Analisis Status GAKY dan Aspek Kesehatan yang Berhubungan dengan Prestasi Belajar Anak Sekolah Dasar di Daerah Endemis GAKY. Kesmas Indonesia: Jurnal Ilmiah Kesehatan Masyarakat, 7(2), 71-81. http:// jos.unsoed.ac.id/index.php/kesmasindo/ article/view/121.

Putri, W., Stephani, M. R., \& Sumarno, G. Early Childhood Motor Development and Body Mass Index: A Demography Study of Children Aged 4-5 Years in Rural Area. Jurnal Pendidikan Jasmani dan Olahraga, 5(1), 1-5.

Riskedas. (2013). Riset Kesehatan Dasar. Badan Penelitian dan Pengembangan Kesehatan, Kementerian Kesehatan RI.

Setiaputri, K. A., Rahfiludin, M. Z., \& Suroto, S. (2017). Hubungan Konsumsi Zat Gizi, Persentase Lemak Tubuh Dan Aktivitas Fisik Dengan Kebugaran Jasmani Pada Atlet Renang. Jurnal Kesehatan Masyarakat (eJournal), 5(3), 166-174. https:// ejournal3.undip.ac.id/index.php/jkm/article/ view/17202

Sugiyono. (2016). Metode Penelitian Kualitatif, Kuantitatif, dan $R$ and $D$. Alfabeta.

Syafei, M., Budi, D. R., Nanang, M., Kusuma, H., \& Listiandi, A. D. (2020). Identifikasi Keberbakatan Menggunakan Metode Australian Sport Search Terhadap Kesesuaian Cabang Olahraga Pada Anak Sekolah Dasar. Physical Activity Journal, 1(2), 99-106. https://doi.org/https:// doi.org/10.32424/1.paju.2020.2.1.2285

Wahono, B. S., Febriani, A. R., \& Heza, F. N. (2019). Fun Water Activity Sebagai Upaya Pencegahan Overweight Pada Anak. Physical Activity Journal, 1(1), 61-68. https:// doi.org/10.32424/1.paju.2019.1.1.2003 